\title{
Spinal Cord Meningioma
}

National Cancer Institute

\section{Source}

National Cancer Institute. Spinal Cord Meningioma. NCI Thesaurus. Code C6935.

A meningioma that affects the spinal cord. 